\title{
A HISTOLOGICAL STUDY OF THE LUNGS IN 52 CASES OF CHRONIC BERYLLIUM DISEASE
}

\author{
BY \\ W. JONES WILLIAMS \\ From the Institute of Pathology, Welsh National School of Medicine, Cardiff
}

(RECEIVED FOR PUBLICATION JULY 5, 1957)

Beryllium disease is a term used to describe the systemic effects of exposure, usually by inhalation, to beryllium and certain of its compounds and it can be subdivided into an acute and a chronic variety. This paper deals with the histological findings in the lungs in chronic beryllium disease. I agree with Hardy (1956) that the alternative term "chronic pulmonary beryllium disease" is unsuitable as it tends to obscure the essentially systemic nature of the disease, though the primary manifestations are usually in the lung.

Beryllium was first identified by Louis Nicolas Vacquelin in 1797. Until recently it was valued only as a component of precious stones but it is now used increasingly in industry, for example, in the production of such metal alloys as stainless steel and chromium and for the screening of uranium in atomic power stations. Other occupations where beryllium is a risk are the making of cathode tubes and $x$-ray machine windows, ceramics, beryllium extraction from ore, and certain experimental work. Beryllium has not been used since 1948 in the manufacture of fluorescent lamps.

Beryllium was soon found to produce toxic effects on inhalation and the earlier papers describe the acute manifestations of a metal-fume type of illness (Weber and Engelhardt, 1933; Fabroni, 1935; Gelman, 1936; Berkovitz and Israel, 1940). One of the earliest North American reports is that of Van Ordstrand, Hughes, and Carmody (1943) who described three acute cases. The earliest reports of a chronic pulmonary disease caused by beryllium came from the U.S.A. (Hardy and Tabershaw, 1946; Gardner, 1946; Higgins, 1947). The disease was the subject of a Saranac Symposium (Vorwald, 1950) and this report provides an excellent summary of knowledge up to that date. Since then a beryllium case registry has been started by Hardy (1955a) which up to date (personal communication) includes
500 cases, 287 chronic and 213 acute, with an overall mortality of $27 \%$. Very few British cases have been reported. The first was by Agate (1948), an example of the chronic type, in a physicist working with fluorescent lamps. Royston (1949) has reported the only acute case to occur in Britain. Sneddon (1955) described a chronic case in a woman of 25 working with $2 \%$ beryllium-copper alloy. The only other report in the British literature is of a skin granuloma caused by a fluorescent tube fragment (Lederer and Savage, 1954). There are two other unpublished British chronic cases, namely, by Teare (1955) in a fluorescent lamp worker and by Rannie (1956) in an experimental chemist.

\section{Materials and Method}

This study is based on the histological examination of material from 52 cases, 49 American, and three British, of which 37 were necropsies and 15 biopsies. When death occurred it followed increasing dyspnoea terminating in cor pulmonale. In a few cases large lung sections were examined. All the cases were examples of chronic beryllium disease. These cases meet Hardy's (1955b) requirements for diagnosis, viz., they all had had a definite exposure to beryllium, a characteristic granulomatous change, and in 27 cases beryllium was demonstrated in the lungs and/or urine.

\section{Method of Exposure}

The mode of exposure and distribution of the cases may be seen in Table 1. The duration of exposure varied widely from two months to 10 years, and a similar interval may exist between the end of exposure and death. There is also a wide variation in the latent interval between initial exposure and onset of disease. The amount of beryllium in the lungs ranged from 0.002 to $435 \mu \mathrm{g} . / 100 \mathrm{~g}$. dried lung, determined spectroscopically (Vorwald, 1950). 
TABLE 1

MODE OF EXPOSURE OF 52 CASES EXAMINED

\begin{tabular}{l|c}
\hline \multicolumn{1}{c|}{ Occupation } & Total \\
\hline Fluorescent lamp industry & $18(1)^{*}$ \\
Living near Be. plant (neighbourhood cases) & 10 \\
Beryllium alloy workers & 9 \\
Beryllium factory worker (type of work unspecified) & 6 \\
Laboratory workers & $4(2)$ \\
No details of exposure & 2 \\
Cathode tube factory & 1 \\
Ceramic factory & 1 \\
Glass factory & 1 \\
\hline
\end{tabular}

* British cases in brackets.

There was no correlation between these figures and the type or extent of the disease. It is of interest that 10 cases were "neighbourhood" ones with indirect exposure to beryllium, such as living down wind of a beryllium factory, washing beryllium workers' clothes, and fishing in the vicinity of a beryllium factory. Examples of such cases are described by DeNardi, Van Ordstrand, and Curtis (1952). Included in this group was a child of 7.

\section{Age and Sex}

The age was available in 46 cases (Fig. 1), ranging from 7 to 64 years. There were 34 men and 18 women for those whose ages were known, and the age distribution of the sexes was similar.

\section{Results}

No difference was discovered between the American and British cases either macroscopically or microscopically.

Gross Anatomy.- The lungs show interstitial

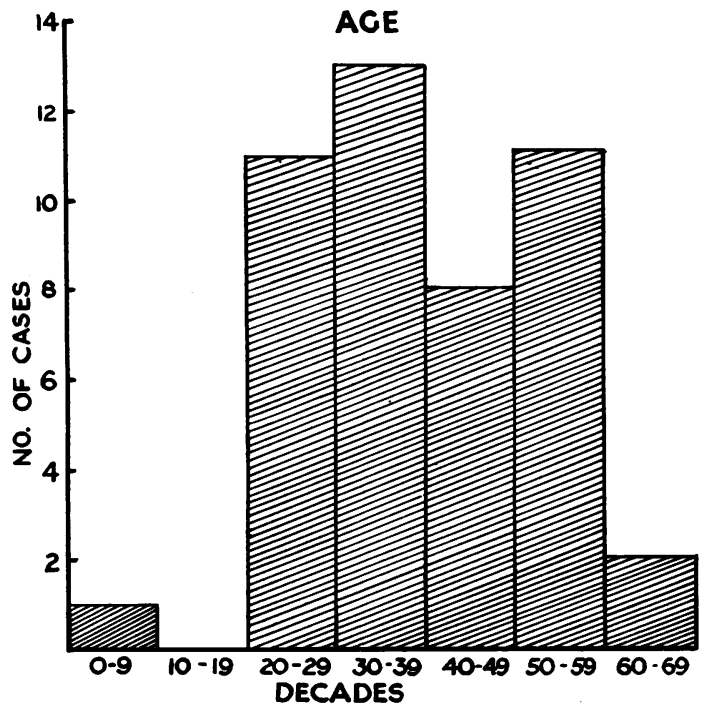

Fig. 1.-Age distribution in 46 cases of beryllium disease.

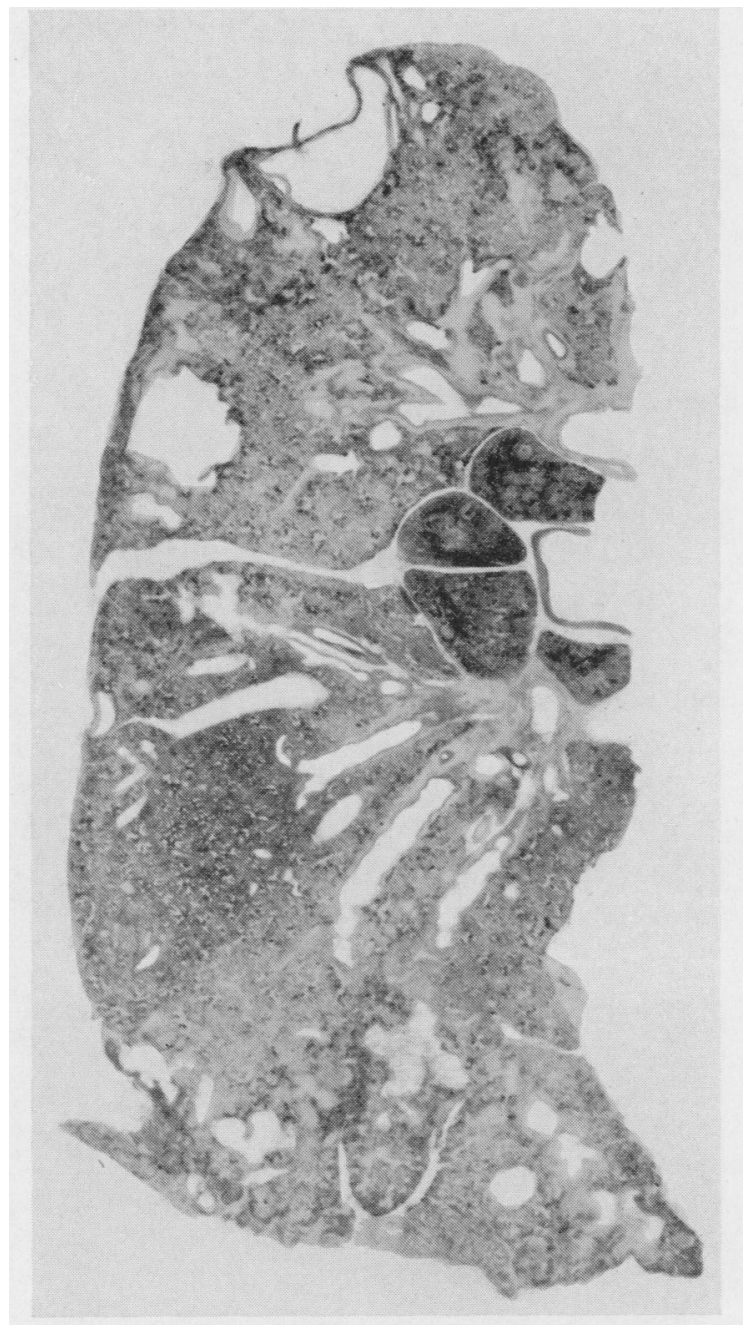

Fig. 2.-Gough-Wentworth large left lung section from a female fluorescent lamp worker. ( $\times 5 / 6)$ showing diffuse fibrosis and cystic change.

fibrosis and in some instances scattered firm nodules a few millimetres in diameter. Emphysema may occur but since the majority of dilated air spaces are thick-walled, "cystic change" is a preferable term. The pleura is usually thickened. Hilar glands may be slightly enlarged and usually show areas of fibrosis. These features are not diagnostic (Fig. 2).

Histological Findings. - The essential lesion is that of a non-caseating, sarcoid type of granuloma situated in the interstitial tissue of the lung and tending to remain discrete (Fig. 3).

The distribution of the granuloma was found to be mainly septal, subpleural, peribronchial, and perivascular, often at the margins of secondary lobules. 


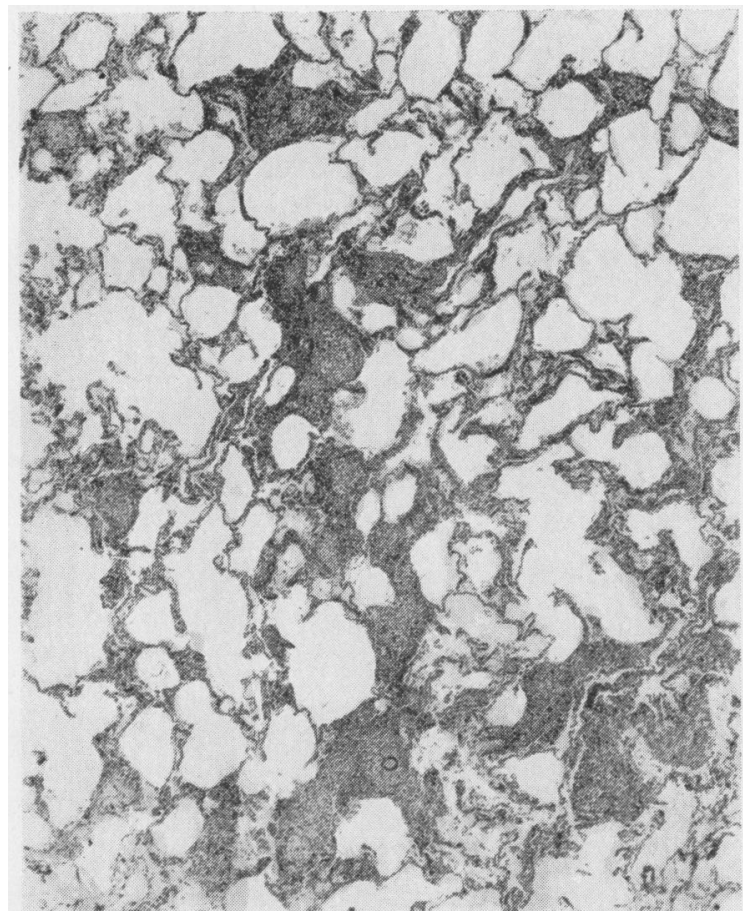

Fig. 3

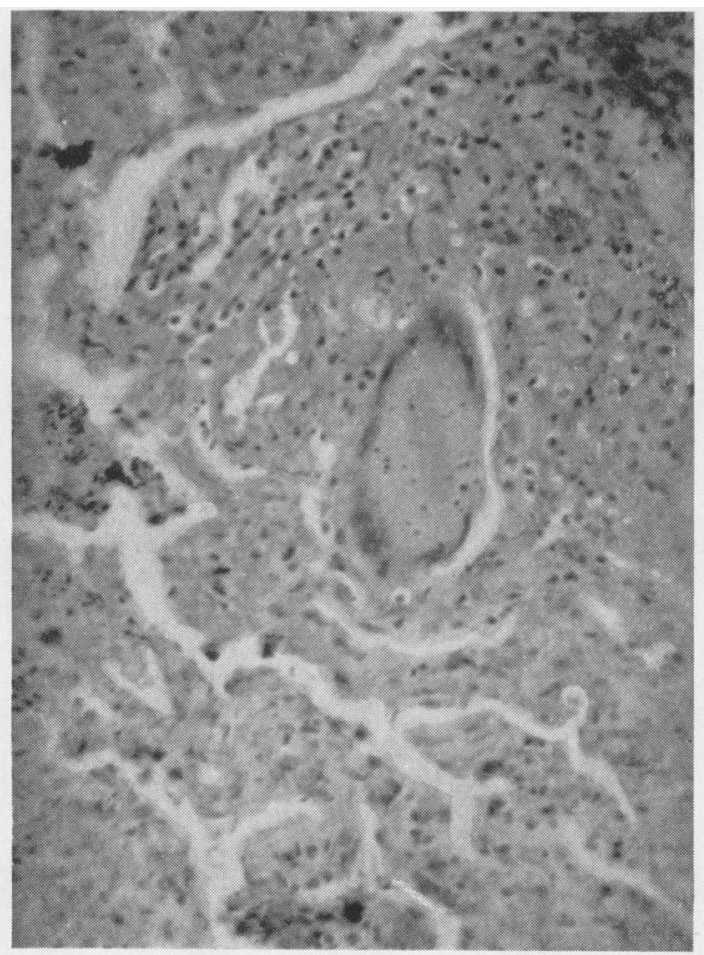

FIG. 5

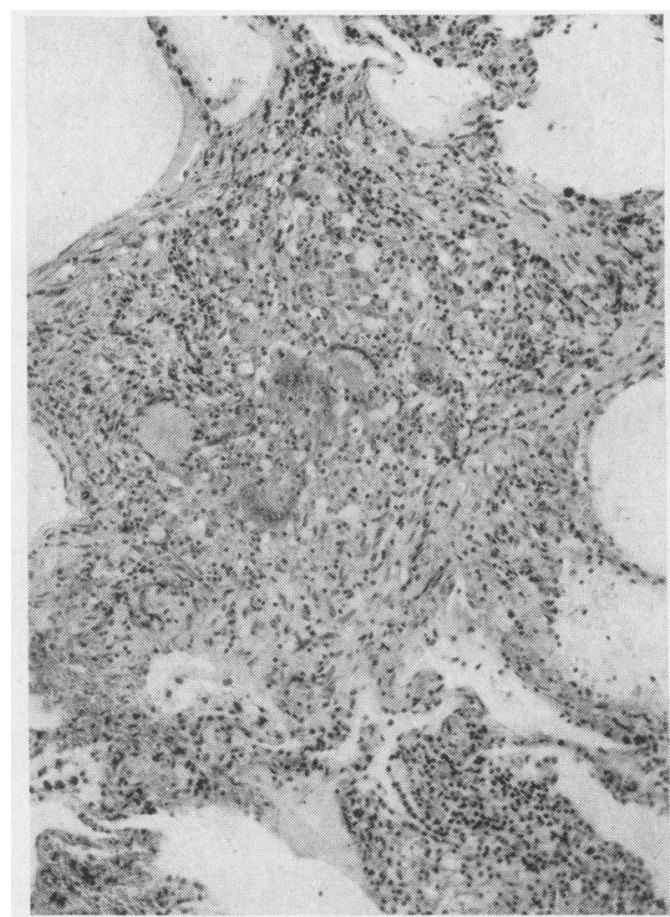

FIG. 4

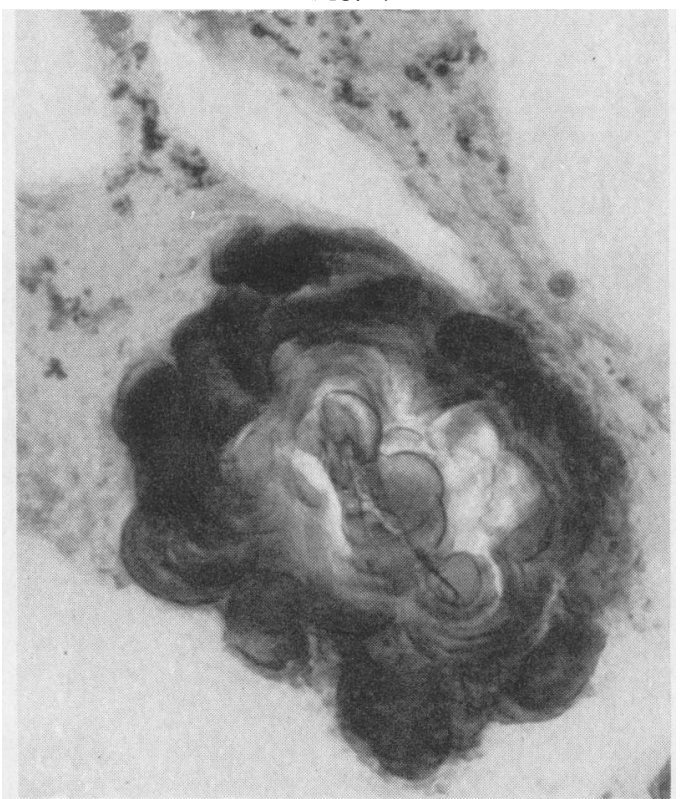

Fig. 6

FIG. 3.-P.T.A.H. $\times 29$. Distribution of lesion in interstitium of lung.

FIG. 4.-Haematoxylin and eosin $\times 105$. Early lesion.

FIG. 5.-Haematoxylin and eosin $\times 300$. Giant cell with central condensation.

Fig. 6. - Haematoxylin and eosin $\times 300$. Conchoidal (Schaumann) bodv. 


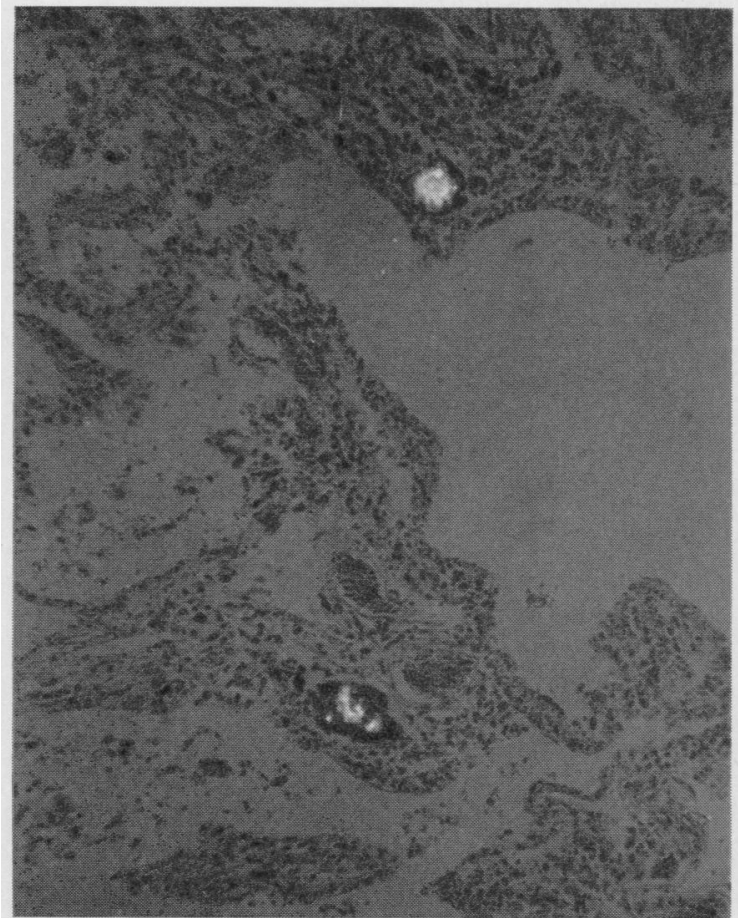

FIG. 7

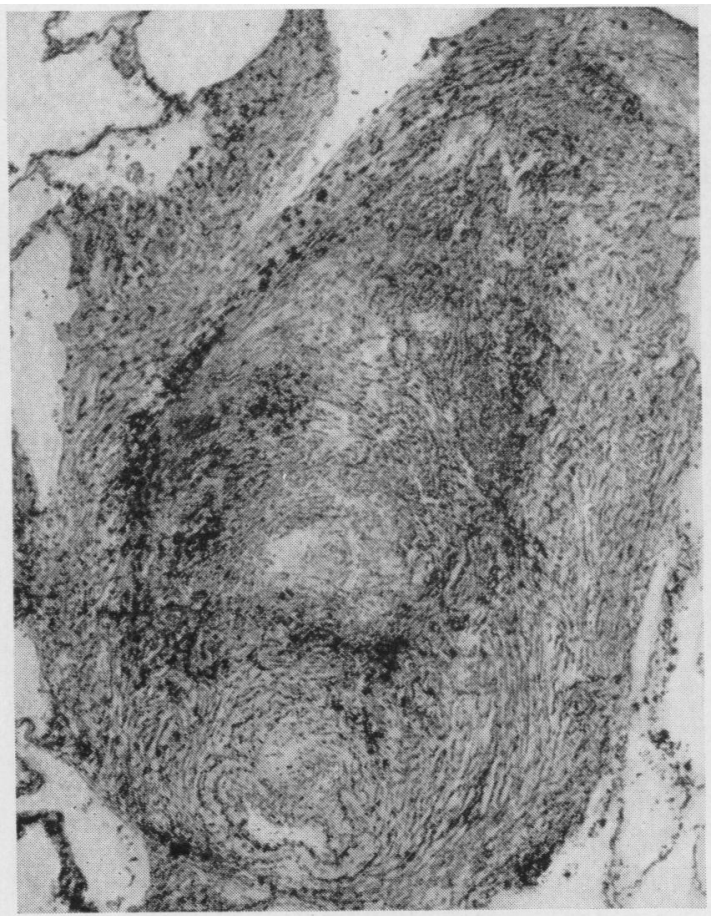

FIG. 9

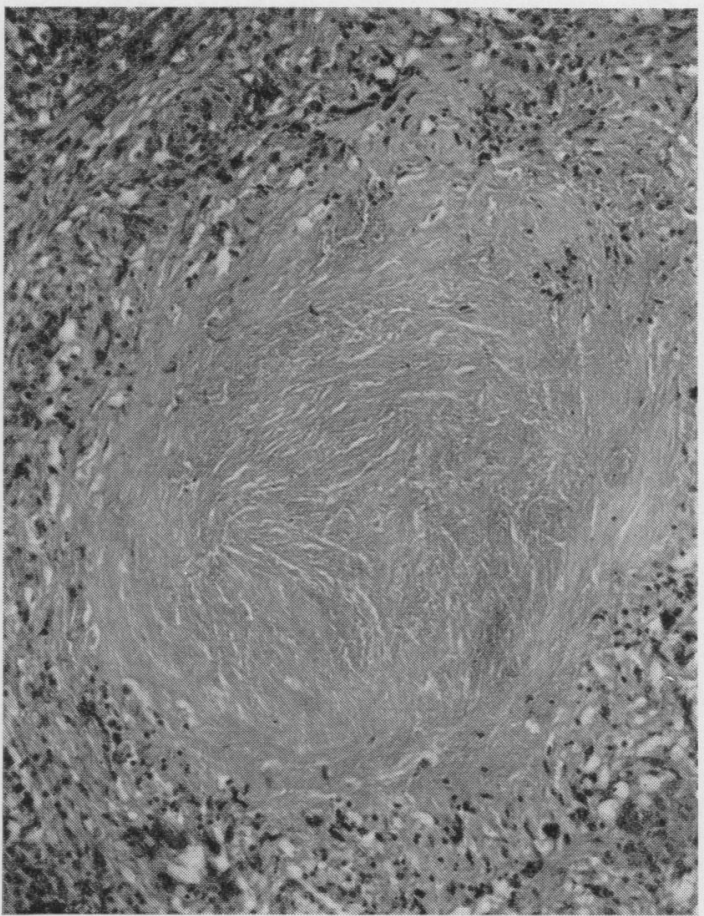

FIG. 8

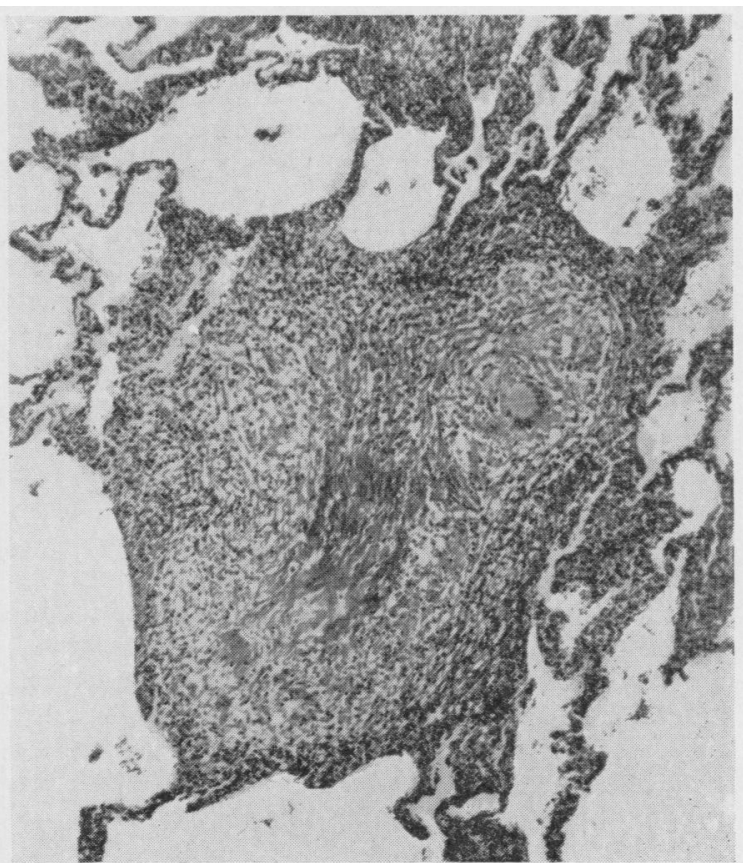

Fig. 10

FIG. 7.-Unstained, polarized $\times 105$. Birefringent crystals.

FIG. 8. - Haematoxylin and eosin $\times 130$. Hyaline change.

FIG. 9.-Reticulin $\times 80$. Hyalinized granuloma.

Fig. 10.-Van Gieson $\times 8$. Hyalinized granuloma. 
The least complex, smallest, and so probably the earliest, lesions consisted of a loose collection of epithelioid cells surrounded by an ill-defined zone of lymphocytes and occasional plasma cells (Fig. 4); eosinophils were absent. As the granuloma increases in size and so probably matures, Langhan type giant cells appear, formed probably by a fusion of epithelioid cells, and occurred in $86 \%$ of cases.

Three types of inclusion bodies may be seen, usually in giant cells and occasionally in epithelioid cells, namely, asteroid bodies, conchoidal (Schaumann) bodies, and crystals.

Asteroid bodies were infrequent and had the same appearance as in Boeck's disease, occurring commonly in giant cells or rarely in epithelioid cells. A possible precursor stage was noticed in that some giant cells showed condensation of the central cytoplasm with increased eosinophilic staining (Fig. 5).

Conchoidal bodies were found in the lesions, but only when giant cells were also present. As the term implies they are shell-like, concentrically laminated calcified bodies, deeply basophilic (Fig. 6). They appear to arise and grow in giant cells and may finally disrupt the cell and become extracellular. As an extracellular structure they may then stimulate the production of foreign-body type giant cells. They measure up to $50 \mu$ in diameter and were present in $42 \%$ of cases.

Crystals may be of two types. Cholesterol crystals were seen in some of the older lesions and identified as empty clefts having been dissolved in paraffin embedding. Occasionally they do not dissolve and remain outlined by calcium and iron salts. The second type of crystals always resists paraffin preparation and persist as brilliantly birefringent single or clumped entities (Fig. 7). They range in size from 3 to $10 \mu$, in their long axis, are usually plate-like, may be spiculated, only rarely needleshaped, and always have a definite sharp edge. They were present in $46 \%$ of cases and it is of interest that $80 \%$ of conchoidal bodies contained these crystals.

It is considered that the cellular lesion is an early phase of the granuloma which becomes finally replaced by fibrous tissue. This is based on the generally accepted observations of human disease and animal experiments that a collagenized lesion may be preceded by reticulin formation which is preceded by a cellular lesion. The central epithelioid cells are progressively obliterated by interlacing strands of hyaline material (Fig. 8), which was seen in $52 \%$ of cases. There is no definite evidence of fibrinoid change in the granuloma. Hyalinization may be distinguished from true caseation by the absence of granularity and of the intermediate basophilic

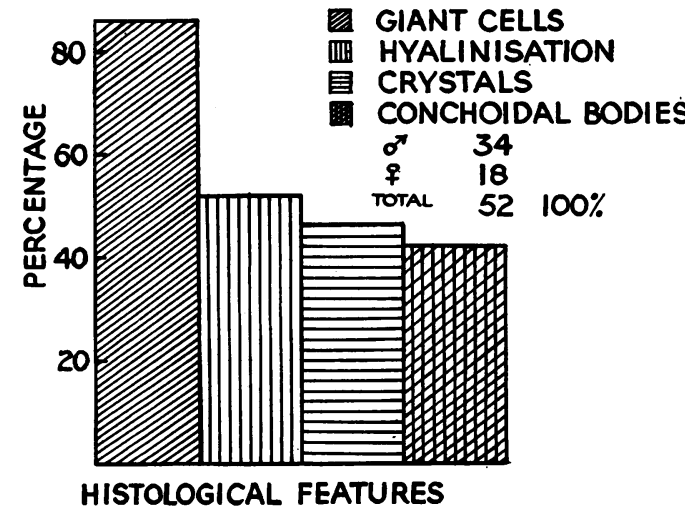

FIG. 11.-Overall percentages of histological features.

stage as seen in the necrosis of tuberculosis. In nine cases the hyaline material showed a tendency to whorling which may be confused with that of a silicotic nodule, but it is of interest that in seven of these silica exposure could not be excluded. The staining reaction of the hyaline material revealed increased reticulin formation with age (Fig. 9) and the development of collagen (Fig. 10). It was negative for amyloid staining, was sometimes faintly positive with P.A.S., and usually positive with molybdate (Pearce) for phosphate. Apart from the conversion of individual lesions into collagen there is a generalized interstitial fibrosis. It is noteworthy that in every case either a cellular or hyalinized granuloma was found, so assisting in a correct diagnosis. The interstitial mural cellular infiltration described by Schepers (1955) was inconspicuous and of no diagnostic value.

The granulomata in hilar glands showed identical features and similar hyaline replacement but rarely progressed to adult collagen. The appearances were not always easy to distinguish from healed tuterculosis.

A statistical test $\left(\chi^{2}\right)$ shows no difference in the incidence of giant cells, hyaline change, crystals, or conchoidal bodies in the two sexes. The overall incidence of these features may be seen in Fig. 11.

There was no difference in the incidence of any histological feature under or over 40 years of age (Table 2).

TABLE 2

THE RELATIONSHIP OF HISTOLOGY TO AGE

\begin{tabular}{l|c|c}
\hline \multicolumn{1}{c|}{ Histology } & $\begin{array}{c}\text { Under 40 Years } \\
(100 \%=25 \text { cases })\end{array}$ & $\begin{array}{c}\text { Over 40 Years } \\
(100 \%=21 \text { cases })\end{array}$ \\
\hline Focal granuloma & $100 \%(25)$ & $100 \%(21)$ \\
Interstitial fibrosis & $100 \%(25)$ & $100 \%(21)$ \\
Giant cells & $84 \%(21)$ & $85 \%(18)$ \\
Crystals & $48 \%(12)$ & $47 \%(10)$ \\
Conchoidal bodies & $48 \%(12)$ & $38 \%(8)$ \\
Hyaline change & $52 \%(13)$ & $52 \%(11)$ \\
\hline
\end{tabular}


No statistical correlation was found between the presence of any histological lesion and the length of exposure or duration of the disease. Approximate figures only were available to the author in a proportion of the cases so that the detailed tables are not included.

Emphysema was not a notable finding in any of these cases, and focal emphysema as seen in coalworkers was not observed (Gough, 1947; Heppleston, 1951).

Alveolar cell proliferation and metaplasia were inconspicuous (Jones Williams, 1957) which is at variance with Schepers' (1955) finding. There were no noteworthy changes in bronchial epithelium. Foam cell clusters and lobular septal cell proliferation, as described by Schepers, Durkan, Delahant, and Creedon (1957) occurring in rats inhaling beryllium, were also inconspicuous and there was no evidence of neoplastic change.

Vascular changes were inconspicuous. There was no evidence of an acute arteritis. Endarteritis obliterans was seen occasionally in some areas of fibrosis.

\section{Discussion}

It is apparent that the histological appearances of the granuloma produced by beryllium closely resemble those seen in Boeck's sarcoid (Hardy and Tabershaw, 1946; Dutra, 1948; Vorwald, 1948). While tuberculosis is often quoted as the important aetiological agent in Boeck's sarcoid, many other agents will produce the same histological lesion, e.g., syphilis, leprosy, histoplasmosis, post-traumatic lesions (King, 1946) or lymph glands in drainage areas of malignant disease (Nadel and Ackerman, 1950). Glass (Ayres, Ober, and Hamilton, 1951) and paradichlorobenzene (Weller and Crellin, 1953) have also been incriminated. Gardner (1937) produced an identical lesion with inhaled silica in guinea-pigs. This is of interest in that the beryllium phosphors used in fluorescent lamp manufacture did contain silicates, zinc manganese beryllium silicate, magnesium silicate, zinc silicate, and varying amounts of free silica in the form of crystobalite. It is therefore imperative to obtain a detailed environmental and occupational history from all patients with suspected Boeck's sarcoid to determine any mineral exposure, especially to beryllium and possibly to silica. Nine cases $(17 \%)$ in the present series showed whorled silicotic type nodules. The beryllium phosphors used in lamp manufacture consist mainly of silicates. Silicates produce a nonspecific type of fibrosis and not the true whorled fibrosis produced by free silica, thus it is probable that in these nine cases the silicotic nodules were produced by a mixed exposure to free silica and beryllium rather than to the small amount of free silica in beryllium phosphors. Four of the nine cases had such a mixed exposure; three were brass foundry workers and one a chemist who had worked with quartz powders. Unfortunately, very few figures are available of the amount of silica in the lungs of this series. Gardner (1946) in 12 cases found low ash values varying from $1 \%$ to $3 \%$ (silicosis $3 \%$ to $34 \%$ ) with a maximum silica in the ash of $4.36 \%$ (silicosis $7.29 \%$ ). It is also recognized that tuberculosis can produce a whorled silicotic type nodulc. In none of these $\mathbf{5 2}$ cases was there evidence of active tuberculosis. Further, the frequency of Mantouxpositive reactors in beryllium disease does not differ from that seen in the general population (Hardy, personal communication). It is therefore unlikely that tuberculosis was the cause of the silicotic type nodules in these patients. McLaughlin (1955) states that beryllium and silica are no longer used in fluorescent lamp manufacture and this has been true in the United States since 1949 (Hardy, 1955b).

The complete similarity of American and British cases both macroscopically and histologically is noteworthy. It is, however, surprising that so few cases have been reported in Great Britain and probably reflects the small number of exposed workers compared with the number in America and possibly missed cases and/or better industrial hygiene.

About $80 \%$ of cases of Boeck's sarcoid collected by Siltzbach (1955) were under the age of 40 , compared with $48 \%$ in this series of chronic beryllium disease. This represents the age scatter in the cases at risk. The age of the patient did not influence the incidence of any histological feature.

The prognosis shows a considerable divergence. Hardy (personal communication) states that there is a $27 \%$ case mortality rate in chronic beryllium disease while Löfgren (1953) expressed the majority opinion that about $90 \%$ of cases of Boeck's sarcoid recover completely. Hardy (1956) discusses the differential clinical features of beryllium poisoning and sarcoidosis.

In Boeck's sarcoid the sexes are equally affected (Longcope and Freiman, 1952). In the present series $30 \%$ of the cases were women.

Dutra (1948) and Vorwald (1948) describe emphysema as being a frequent finding. The paucity of emphysema in the present cases is notable but may be because the complete lungs were seldom available for study. The material was, however, suitable for the evaluation of focal emphysema but this was absent. So beryllium and silica, unlike coal, do not produce focal emphysema. This is probably a manifestation of the degree of fibrosis, as very little collagen is seen in simple coalworkers' pneumo- 


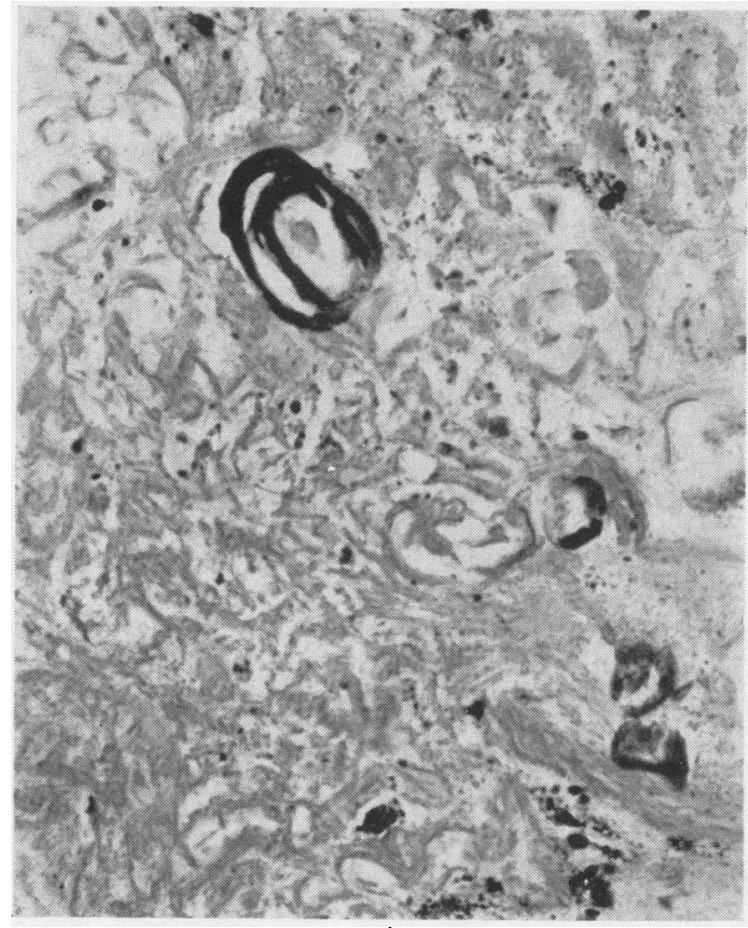

FIG. 12.- Haematoxylin and eosin $\times 520$. Conchoidal body in tuberculosis.

coniosis compared with a moderate amount in chronic beryllium disease and an excess in silicosis.

It is difficult to prove the exact nature of the hyaline change. It is emphasized that it is probably a gradual process and unlike the rapid necrosis of tuberculous caseation. It is, however, similar to the change seen in Boeck's sarcoidosis. The hyaline change is unlikely to be due to any specific arterial change; the occasional vessel showing endarteritis might as well be post hoc as propter hoc.

Asteroid bodies were uncommon in these cases and are of no assistance in diagnosis as they are often seen in other conditions, for example, in Boeck's sarcoid (Longcope and Freiman, 1952), in retention cyst of the breast, and in sebaceous cysts (Hirsch, 1935). Ricker and Clark (1949) state that they are commoner in tuberculosis, leprosy, histoplasmosis, schistosomiasis, and lipoidal granulomata than in Boeck's sarcoid.

Conchoidal bodies were found in $42 \%$ of these cases compared with Dutra's (1948) series where they occurred in 11 out of 13 cases. They are common in Boeck's sarcoid and occur in tuberculosis (Schaumann, 1941) and so again are not a diagnostic feature. Fig. 12 illustrates a conchoidal body in tuberculosis and Fig. 13 one in a silicotic nodule.

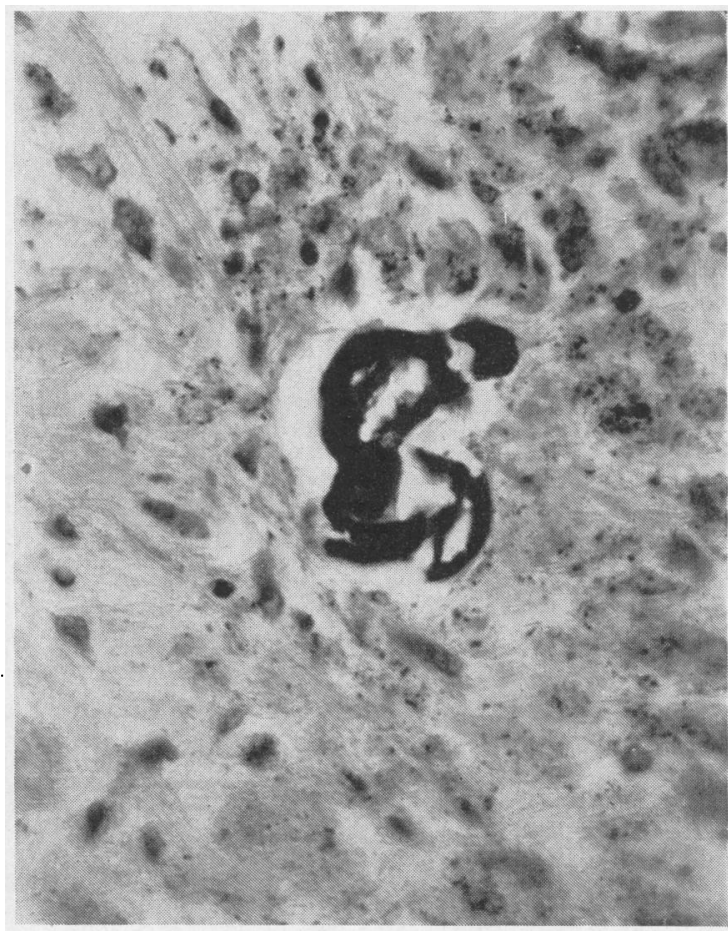

FIG. 13.-Haematoxylin and eosin $\times 540$. Conchoidal body in silicosis.

Similar bodies are also described in multiple myeloma of the kidney (Apitz, 1940). Doniach and Wright (1951) described them in pituitary granuloma.

Cholesterol crystals are also non-specific and are often found in any area of tissue necrosis.

Birefringent crystals have been described in Boeck's sarcoid (Teilum, 1949; Cid, 1950; Engle, 1953; Longcope and Freiman, 1952), but their exact nature is still a matter of dispute. These crystals are identical with those found in the present series and so are not a diagnostic feature of chronic beryllium disease.

It is of interest that the histological findingsfocal granuloma, interstitial fibrosis, hyaline change, giant cells, conchoidal bodies, and birefringent crystals-were not influenced by the length of exposure or the duration of illness.

The clinical features of a positive beryllium patch test (DeNardi, Van Ordstrand, Curtis, and Zielinski, 1953) and the development of a systemic disease after the inhalation of very small amounts of beryllium compounds favour the contention that the disease is a manifestation of hypersensitivity. However, in the absence of definite fibrinoid change, eosinophilia, and acute arteritis, the histological evidence does not support this theory. 


\section{Summary}

The histological features of 52 cases, 49 American and three British, of chronic beryllium disease affecting the lungs are described. There was no difference between the American and the British cases. The histological lesion begins as a focal granuloma with a gradual transition to fibrous tissue and an associated interstitial fibrosis. The features are indistinguishable from Boeck's sarcoid. Thus for diagnosis a history of beryllium exposure and the demonstration of beryllium in tissues are essential. The following histological features and their incidence are described and discussed: Focal granuloma $(100 \%)$, interstitial fibrosis $(100 \%)$, giant cells $(86 \%)$, hyaline change $(52 \%)$, birefringent crystals $(46 \%)$, conchoidal (Schaumann) bodies $(42 \%)$.

Most of this material was collected during the tenure of a British Empire Cancer Campaign American-British Exchange Fellowship.

I wish to thank Dr. Harriet Hardy for her kind cooperation and access to her beryllium registry, Dr. G. W. H. Schepers, Dr. H. S. Van Ordstrand, and Dr. A. J. Vorwald for access to material. Dr. D. Teare and Dr. I. Rannie kindly gave me material and details of their cases. The other British case became available through the courtesy of Professor J. Gough.

\section{REFERENCES}

Agate, J. N. (1948). Lancet, 2, 530.

Agate, K. (1940) Virchows Arch. path. Anat., 306, 631.

Ayres, W. W., Ober, W. B., and Hamilton, P. K. (1951). Amer. J. Pat. 27,303 .

Berkovitz, M., and Israel, B. (1940). Klin. Med., 18, 117.
Cid, J. M. (1950). An. Cir. (Rosario), 15, 115.

DeNardi, J. M., Van Ordstrand, H. S., and Curtis, G. H. (1952). Cleveland Clin. Quart., 19, 171., (1953). A.M.A. Arch. industr. Hyg., 8, i.

Doniach, I, and Wright, E. A. (1951). J. Path. Bact., 63, 69.

Dutra, F. R. (1948). Amer.J. Path., 24, 1137.

Engle, R. L. (1953). Ibid., 29, 53.

Fabroni, S. M. (1935). Med. d. Lavoro, 26, 297.

Gardner, L. U. (1937). Amer. J. Path., 13, 13.

(1946). Proc. Xi Annual Meeting Industrial Hygiene Foundation of America, Pittsburgh.

Gelman, I. (1936). I. industr. Hyg., 18, 371

Gough, J. (1947). Occup. Med., 4, 86.

Hardy, H. L. (1955a). Amer. Rev. Tuberc., 72, 129.

(i955b). A.M.A. Arch industr Hlth i2, 174.

(1956). Amer. Rev. Tuberc., 74, 885.

- and Tabershaw, I. R. (1946). J. industr. Hyg., 28, 197.

Heppleston, A. G. (1951). A.M.A. Arch. industr. Hyg., 4, 270.

Heppleston, A. G. (1951). A.M.A. Arch. indu.
Higgins, H. L. (1947). Conn. med. J., 11, 330.

Higgins, H. L. (1947). Conn. med. J., 11, 330.
Hirsch, E. F. (1935). Arch. Path. (Chicago), 20, 665.

Hirsch, E. F. (1935). Arch. Path. (Chicago), 20, 665.

King, C. O. (1946). Sth. med. J. (Bgham, Ala.), 39, 122.

Lederer, H., and Savage, J. (1954). Brit. J. industr.
Löfgren, S. (1953). Acta. med. scand., 145, 424.

Longcope, W. T., and Freiman, D. G. (1952). Medicine (Baltimore), 31, 1 .

McLaughlin, A. I. G. (1955). A.M.A. Arch. industr. Hlth, 12, 83

Nadel, E. M., and Ackerman, L. V. (1950). Amer. J. clin. Path., 20, 952 .

Rannie, I. (1956). Paper read to Pathological Society of Great Britain and Ireland, July, 1956. (See also Editorial, Brit. med. J. [1956], 1, 1224.)

Ricker, W.. and Clark, M. (1949). Amer. J. clin. Path., 19, 725.

Royston, G. R. (1949). Brit. med. J., 1, 1030.

Schaumann, J. (1941). Acta. med. scand. 106, 239.

Schaumann, J. (1941). Acta. med. scand., 106, 239. Found. Pittsburgh, p. 139. . B. and Creedon, F. T. (1957).

- - Durkan, T. M., Delahant, A. B., and Creedon, F. T. (1957).

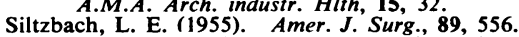

Sneddon, I. B. (1955). Brit. med. J., 1, 1448.

Teare, D. (1955). Unpublished.

Teilum, G. (1949). Amer. J. Path., 25, 85.

Van Ordstrand, H. S., Hughes, R., and Carmody, M. G. (1943). Cleveland Clin. Quart., 10, 10.

Vorwald, A. J. (1948). Occup. Med., 5, 684.

[ed.] (1950). Pneumoconiosis: Leroy U. Gardner Memorial Volume. (Sixth Saranac Symposium, 1947.) Hoeber, New York.

Weber, H. H., and Engelhardt, W. E. (1933). Zbl. GewHyg., n.s., 10,41 .

Weller, R. W., and Crellin, A. J. (1953). Arch. intern. Med., 91,

Williams, W. Jones (1957). Brit. J. Cancer, 11, 30. 